Katarzyna Niesporek

Uniwersytet Śląski w Katowicach

\title{
Zagłada zwierząt i ludzi. Lektura Poematu o miejskiej rzé́ni Tadeusza Śliwiaka
}

\section{Zwierzęta i ludzie}

Poemat o miejskiej rzeźni to szósty tom wierszy Tadeusza Śliwiaka, opublikowany w 1965 roku przez Wydawnictwo Literackie w Krakowie. „Po pierwszym wydaniu ukazał się on jeszcze drukiem sześciokrotnie, a także doczekał się kilkunastu inscenizacji teatralnych" (Śliwiak 1988: 8). Książkę tę uważa się za moment przełomowy w twórczości poety. Po pierwsze, wyróżnia się ona na tle jego pozostałych tomów inną, mniej imaginacyjną poetyką, po drugie - nawiązuje do traumatycznych przeżyć związanych z dzieciństwem i młodością, których grozę i prawdziwy wymiar okrucieństwa twórca zrozumiał i uświadomił sobie dopiero później. „Tym utworem - uważał Konstanty Pieńkosz - «powinien» Śliwiak debiutować. W jego biografii Poemat jest tym, czym dla Różewicza Niepokój, dla Miłosza Ocalenie" (Pieńkosz 1986: 8). Chociaż autor Widnokresu (urodzony w 1928 roku) nie należał do pokolenia Kolumbów (w latach 1939-1945 miał od 11 do 17 lat), wojna odcisnęła na nim piętno. Zawarta w tytule tomu i poematu miejska rzeźnia to przestrzeń konkretna i autentyczna, umiejscowiona we Lwowie przy ulicy Nowej Rzeźni 51. Śliwiak we wstępie do Poezji wybranych z roku 1975 wspominał:

Rzeźnia była dla mnie najważniejszą chłopięcą pamięcią wyniesioną z wojny. W czasie okupacji hitlerowskiej mieszkałem wraz z rodzicami 
i rodzeństwem na terenie Miejskiej Rzeźni we Lwowie. Otoczona wysokim murem z czerwonej cegły, była jakby wydzielonym miasteczkiem. Ojciec mój skorzystał z możliwości podjęcia tam pracy kierowcy samochodowego i w ten sposób uniknął aresztowania przez hitlerowców. $\mathrm{Z}$ okna naszego mieszkania oglądałem ogromny budynek chłodni i hale, gdzie zabijano zwierzęta. [...] Oglądałem okrucieństwo, przemoc i „przemysłową śmierć” zwierząt. Wszystko to, poszerzone o wymiar toczącej się wojny - kojarzyło się z losem ludzi mordowanych w obozach i rozstrzeliwanych na ulicach i placach miast (Śliwiak 1975: 9-10).

Rzeźnia posiada tu co najmniej kilka znaczeń. Jakiekolwiek z nich wzięłoby się pod uwagę, za każdym razem stanowi ona miejsce straszne, przestrzeń, w której rozgrywają się okrutne wydarzenia. Zapamiętana przez autora Chityny, po pierwsze jest „Wielką Metaforą” wojny (Sobolczyk 2009: 32), po drugie przypomina getto, gdyż w rzeźni „zatrudniano [...] skazanych na zagładę Żydów z obozu Janowskiego we Lwowie" (Pieszczachowicz 1988: 163). Sama zaś, opisana przez poetę, śmierć zwierząt przywodzi na myśl eksterminację ludzi. Dla Śliwiaka, który był obserwatorem dwóch rzeczywistości - rzeźni i obozu - los zwierzęcia i człowieka zdaje się właściwie identyczny. Twórca przekonuje, że podczas wojny dokonały się dwie zagłady. Pierwsza - ludzka, druga - zwierzęca. Żadnej nie chce deprecjonować (Sobolczyk 2009: 28-40). Więcej: dla niego, jako młodzieńca, zagłada zwierząt, chociaż go nie przerażała, stanowiła zdumienie, gdyż w czasie wojny nie była tak oczywista ${ }^{1}$ jak zagłada człowieka. Sławomir Kryska przypominał:

[...] dzieciństwo Śliwiaka przypadło na okres, kiedy śmierć człowieka była czymś nieporównywanie zwyczajniejszym od śmierci zwierzęcia. Znacznie rzadziej można było oglądać cierpienie zwierząt niźli cierpienie ludzi - stąd cierpienie zwierząt było bardziej godne litości; zwierzę znaczyło pożywienie, a człowiek... Tak, każde porównanie człowieka ze zwierzęciem w tamtych czasach wypadło na korzyść zwierzęcia (Kryska 1966: 8).

1 Zabijanie zwierząt hodowlanych i ich okropne traktowanie do dzisiaj pozostaje czymś nieunaocznionym i nieuświadomionym dla wielu. John Maxwell Coetzee napisał: „Powiem otwarcie: wokół nas funkcjonuje olbrzymia fabryka upodlenia, okrucieństwa i mordowania, która dorównuje wszystkiemu, do czego zdolna była Trzecia Rzesza, a w gruncie rzeczy bije ją na głowę pod tym względem, że jest przedsięwzięciem bez końca, samo odradzającym się, produkującym w nieskończoność króliki, szczury, drób, bydło, po to, żeby zabijać" (Coetzee 2006a: 79). 
Śliwiak swoim utworem i postawieniem znaku równości pomiędzy rzeźnią a obozem koncentracyjnym, cierpieniem Żydów i zwierząt hodowlanych, zdaje się powtarzać za Tadeuszem Różewiczem: „To są nazwy puste i jednoznaczne: / człowiek i zwierzę" (Różewicz 2005: 21). Zrównanie gatunkowe, jakiego dokonuje autor Niepokoju za sprawą przewartościowującej wszystko wojny, prowadzi do dalszych, dosadniejszych stwierdzeń: „Człowieka tak się zabija jak zwierzę, „widziałem: / furgony porąbanych ludzi / którzy nie zostaną zbawieni” (Różewicz 2005: 21). Śliwiak dodaje jednak do tych fraz jeszcze inne - które Piotr Krupiński wywiódł z wiersza Ucieczka świnek dwóch ( z obozu zagłady - rzeźni) Różewicza - „Zwierzę tak się zabija jak człowieka”, widziałem: „furgony porąbanych zwierząt, które [...] nie zostaną zbawione” (Krupiński 2016: 269-270)².

Poemat o miejskiej rzeźni jest utworem „unikalnym”, obrazuje „narodziny świadomości emancypacyjnej” i pozbywa się zdefiniowanego przez Petera Singera „szowinizmu gatunkowego” (Sobolczyk 2009: 30). Publikacją książki Śliwiak wkroczył w chętnie podejmowany współcześnie temat zrównywania rzezi zwierząt z ludobójstwem Żydów. Przypomnijmy kilka dobrze już znanych i reprezentatywnych wypowiedzi w tym zakresie: „W swym zachowaniu wobec zwierząt wszyscy ludzie są nazistami” (cyt. za: Singer 2018: 133); „Przez cały czas pobytu w tych rzeźniach myślałem o obozach koncentracyjnych. Jest to Auschwitz dla zwierząt” (Cioran 2004: 476), „Auschwitz zaczyna się wszędzie tam, gdzie ktoś patrzy na rzeźnię i myśli: to tylko zwierzęta” (Patterson 2003: 68), „Historia ludzkości odsłania pewien schemat - najpierw ludzie eksploatują i zarzynają zwierzęta, a później traktują innych ludzi jak zwierzęta, czyniąc z nimi to, co ze zwierzętami” (Patterson 2003: 131), „Wrócę po raz ostatni do otaczających nas miejsc zagłady, miejsc rzezi, przed którymi, w wielkim zbiorowym wysiłku zamykamy serca. Codziennie odbywa się nowy holokaust, a jednak najwyraźniej nasze morale pozostaje nieporuszone, nietknięte” (Coetzee 20o6a: 96), „Żydzi umierali jak bydło, a zatem bydło umiera jak Żydzi” (Coetzee 2006b: 112).

Skojarzenie rzeźni z Holokaustem staje się zatem szczególnie silne po drugiej wojnie światowej. Poeta, będąc świadomy, że „rozliczenia z przeszłością

2 Refleksja o rzezi i rzeźni rozpoczyna się w polskiej poezji już w 1929 roku - od wiersza Józefa Czechowicza pt. Śmierć, w którym pojawiają się następujące frazy: „wagon czerwone więzienie krów / zatkał okienka pyskami cieląt / ryk żalem kipi ryk i znów / maszyny ciszę mielą”, „o koła których 8 / dobrze wy wiecie gdzie rzeźnia / im hamulcom przyczepom osiom / droga też nie bezbrzeżna // dlaczego deski przepojone smarem / przestały być kwitnącymi sosnami / dlatego i ceglany dom / stacja towarowa z żelaznym dźwigarem / nie zmiłuje się nad nocą i krowami // krowy na zabicie są" (Czechowicz 1970: 28-29). Więcej na ten temat pisała także Anita Jarzyna w książce Post-koine. Studia o nieantropocentrycznych językach (poetyckich) (Jarzyna 2019: 28, 177, 227-228). 
i troska o przyszłość powojennego pokolenia, starania o rozwój ekonomiczny i zapewnienie dobrobytu przesłoniły kwestię zwierzęcą i problem etyczny przemysłowego uboju zwierząt" (Loba 2017: 42-43), pisze Poemat..., który jest reakcją na niczym niezawinione cierpienie i stanowi stanowczy sprzeciw wobec jego ignorancji i wykluczeniu.

\title{
2. Dzieciństwo i młodość w rzeźni
}

Śliwiak, dzieląc tom na dwie główne części - Poemat o miejskiej rzeźni (złożony z dwunastu układających się w cykl utworów pisanych w latach 1962-1963) oraz Przejście przez Morze Czerwone (składający się z trzynastu osobnych wierszy) rozpoczyna swoją poetycką wypowiedź od przywołania wątków autobiograficznych. Liryk otwierający Poemat... nosi tytuł Ogrody. Okazuje się jednak, że są one po pierwsze metaforą kilku przestrzeni (dlatego nie bez przyczyny poeta zastosował w tytule liczbę mnogą): rzeźni/getta i obozu koncentracyjnego, które tak jak ogród są odrębnymi, wydzielonymi od reszty świata miejscami; po drugie (w nawiązaniu do Edenu) - kładą nacisk na pierwotne miejsce istnienia człowieka, którym w przypadku poety było mieszkanie usytuowane na terenie miejskiej rzeźni. Przywołując dzieciństwo i młodość, wskazując wyraźnie na swój rodowód, twórca Żywicy napisał:

\author{
wywodzę się z rzeźni \\ dom z czerwonej cegły \\ mur \\ żelazna brama \\ strażnik z karabinem \\ nasze służbowe mieszkanie \\ z obniżonym czynszem \\ to tylko rzeźnia \\ hale trzy \\ żelazne wózki \\ haki w murze \\ korytka dla odpływu krwi \\ i ogród dyrektora \\ róże
}

$\left(\text { Ogrody, } \mathrm{P}_{5-6}\right)^{3}$

3 Wszystkie cytowane w szkicu utwory pochodzą z tomu Tadeusza Śliwiaka zatytułowanego Poemat o miejskiej rzeźni (Śliwiak 1965). Po tytule wiersza podaję skrót P i numer strony. 
Miejsce dzieciństwa jest heterogeniczne, dla dziecka zapewne trudne jednoznacznie do zdefiniowania. Wiele w nim sprzeczności. Autor Widnokresu „[...] służbowe mieszkanie / z obniżonym czynszem” nazywa wielokrotnie w swoich utworach domem ${ }^{4}$. Nie okala go jednak - jakby zapewne chciał chłopiec - bujny ogród, ale kamienna i surowa przestrzeń zakładów mięsnych, w której wszystko zostało dobrze przemyślane i starannie rozmieszczone. Natury Śliwiak szukał wówczas gdzie indziej: „Niedaleko domu rosły stare kasztany. Było ich dużo. Lubiliśmy je, my, tamtejsi chłopcy. Były długo zielone. Jak długie wakacje, jakich prawdziwie zaznaliśmy dopiero po wojnie" (Śliwiak 1975: 10). Przestrzenna organizacja ubojni, podział pracy w rzeźni oraz panujące w niej ład i dyscyplina, których pilnował „strażnik z karabinem”, kojarzą się z miejscami zagłady Żydów. Poszczególne, składające się na rzeźnię pomieszczenia i przedmioty, naznaczone są cierpieniem zwierząt, wykluczającym bezpieczeństwo i ciepło, z jakimi kojarzy się dom. „Mur” zastępuje tu płot, „żelazna brama” - furtkę, „korytka dla odpływu krwi” - rynny, „hale trzy” - przytulne pokoje, „haki w murze” wieszaki na ubrania, „żelazne wózki” - dziecięce zabawki. Już same dające się wyprowadzić z przytoczonego fragmentu wiersza określenia: „dom w rzeźni”, „mieszkanie w rzeźni”, „ogród w rzeźni”, „róże w rzeźni” są oksymoroniczne. Ale to, co dla czytelnika Poematu... może być okrutne, dla młodego Śliwiaka stanowiło codzienność. Dla dziecięco-młodzieńczego podmiotu opisywane otoczenie nie jest przerażające: „To tylko rzeźnia” (wyróż. - K.N.). Miejsce, do którego przywykł, o wiele lepsze aniżeli inne miejsca w wojennej rzeczywistości, choćby niedaleko znajdujący się obóz koncentracyjny. „Szczęście” schronienia w ubojni ma jednak swoją wysoką cenę:
Uczyłem się życia
od śmierci
wcześniej widziałem
nóż w ręce rzeźnika
niż pastucha $z$ kijem
moje pierwsze ogrody
to mięs cyprysy czerwone

4 W dwunastym wierszu pierwszej części Poematu o Miejskiej Rzeźni Śliwiak napisał: „Przetrwał mój dom / z czerwonej cegły / w gęstym lesie dymów wysokich / przetrwał mój dom / z dziurami w murze / oblepiony listami rozstrzelanych / przetrwał mój dom / czerwony jak pamięć / boję się tam powrócić / obchodzę go dookoła / ilekroć sięgnę do kieszeni / po tytoń / po ziarno dla ptaków / zawsze znajduję / klucz od bramy / od bramy mojego czerwonego domu / wrzucałem go do wody / ciskałem do ognia / zakopywałem w ziemi // wracał i mówił / jestem twoim sercem" (Klucz, P 15). 


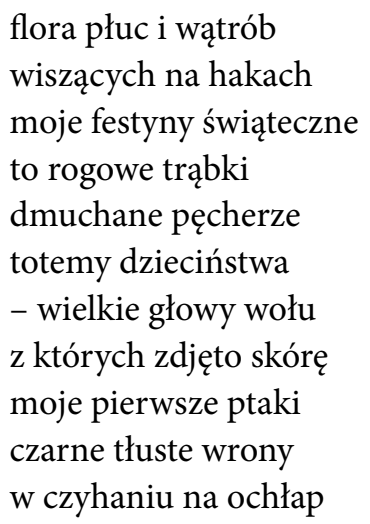

(Ogrody, $\mathrm{P}_{5-6)}$

Atmosfera rzeźni i okupacji znacząco odwraca porządek poznania w każdej sferze egzystencji chłopca. Dzieciństwo zostaje zamienione na dorosłość zdominowaną przez śmierć, laska pasterska na rzeźniczy nóż, troszczący się o zwierzęta pasterz na wyzutego z uczuć rzeźnika-mordercę, wreszcie beztroskie, zielone i górskie pastwiska $z$ owcami na rzeźnię wypełnioną surowym mięsem - baraniną i jagnięciną. Przywołane przez poetę dawne zwierzęta ofiarne stanowią symbol prostoty, niewinności i łagodności, których podmiot wierszy w wojennej rzeczywistości nie mógł doznać. To m.in. dlatego szczególna, emocjonalna relacja, jaka zwyczajowo zostaje zawiązana pomiędzy dziećmi i zwierzętami, u młodego Śliwiaka początkowo nie ma miejscas. Staje się on za to świadkiem ich codziennej, krwawej ofiary, co sprawia, że jego psychosferę wypełniają przede wszystkim turpistyczne sceny i przedmioty. Nie zawierają one w sobie ani trochę subtelności, która mogłaby złagodzić otaczającą dziecko okrutną rzeczywistość ubojni. To, co zostaje ukazane jego oczom, jest w pełni realne. Dla autora Widnokresu, który innego świata nie zna, to wszystko, na co spogląda, nie jest wstrząsające, ale normalne - budzi w nim ciekawość, kształtuje wyobraźnię. Poeta, patrząc z perspektywy dzieciństwa/młodości, miesza obrazy przyrody i ubojni. Te drugie zdecydowanie przeważają. „Czerwone cyprysy” podmiot

5 Zwierzętami, z którymi osoba mówiąca zawiązuje pewien rodzaj więzi w drugiej części tomu, są: czarny baranek, gołąb i pies. O dwóch ostatnich poeta wspomina dopiero w wierszu Wrony: „Kupiłem białego gołębia. Gołębie są ładniejsze od wron, ale nie chcą jeść mięsa. Dostałem od Michała śmiesznego szczeniaczka. Nazywał się Rudolf Rdza. Rósł i weselał razem ze mną. Było mu dobrze. Spośród czworonogów, które przekroczyły bramę rzeźni, on jeden nie został zjedzony" (Wrony, P 33). 
kojarzy z „mięsem”, „flora” nie określa roślinności, ale bakterie, które są częścią „[...] płuc i wątrób / wiszących na hakach”, totemy nie są drewnianymi rzeźbami, będącymi ozdobą ogrodu, ale „[...] głowami wołu / z których zdjęto skórę”. Ubojnia staje się dla chłopca swego rodzaju obserwatorium, miejscem poznania zwierzęcego świata od podszewki, unaocznieniem - od momentu znalezienia się zwierząt w rzeźni - kolejnych etapów, składających się na ich tragiczny los: transport - zamknięcie - ubój - obdarcie ze skóry - mięso - przetworzenie go na pożywienie lub inny produkt. Dziecięco-młodzieńcze ogrody Śliwiaka są więc przeznaczone do zabijania zwierząt: „[...] okrucieństwo doświadczane przez tzw. zwierzęta hodowlane w chowie przemysłowym” stanowi „metaforę obozu zagłady" (Szaj 2017: 127):

Przemysłowa hodowla odbywa się bowiem tak, „jakby, zamiast upychać ludzi w piecach albo komorach gazowych, doktorzy i genetycy zadecydowali, by za pomocą sztucznego zapładniania doprowadzić do przeludnienia i nadprodukcji pokoleń Żydów, Cyganów, homoseksualistów, tak by, o wiele liczniejsi i o wiele lepiej wykarmieni, mogli zostać przeznaczeni do tego samego piekła o wciąż rosnących rozmiarach" (Szaj 2017: 127-128).

Hodowla i ubój zwierząt nie są jednak postrzegane przez chłopca w taki sposób, jak zostało przed chwilą zacytowane. Poeta - dorastające dziecko spogląda na ogrody Zagłady - mówiąc za Krupińskim - „Z perspektywy «poza dobrem i złem»" (Krupiński 2016: 59). Zabijanie zwierząt, które z ciekawością obserwuje, służy raczej edukacji, dopiero kształtuje jego świadomość. W rzeźni, codziennej rzeczywistości istnienia, odnajduje np. służące do zabawy „rogowe trąbki”. Młody Śliwiak nie wie jeszcze, że jego rozrywka odbywa się kosztem cierpienia zwierząt. „Groza - jak zauważył Pieńkosz - nie bije wprost ze słów poety, są one powściągliwe, relacja «jest podszyta dzieckiem»” (Pieńkosz 1986: 11).

\section{Krowy w rzeźni}

W Poemacie o miejskiej rzeźni obserwujemy los krów od momentu przetransportowania ich do ubojni. W części zatytułowanej Węgiel poeta, wcielając się w rolę obserwatora, który relacjonuje życie związane z rzeźnią, napisał:

Wyświecone są szyby bocznicy

jadą jadą krowy do rzeźni

jedzie jedzie mięso na wschód 


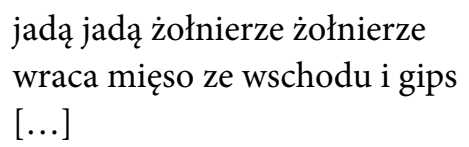

W opisach kolejnych etapów zabijania zwierząt zostaje pominięty sielankowy czas wypasu na pastwiskach i uszczęśliwiający krowy kontakt z cielętami. Moment, w którym są zaganiane do środka transportu, skazuje je na zamknięcie i pewną śmierć. Zwierzęta jako istoty świadome odczuwają niepokój, zachowują się tak, jakby wiedziały, że są „prowadzone na rzeź”. Transport dynamizuje dotąd spokojne życie zwierząt. Ekspresyjne sformułowania: „jadą jadą krowy [...]”, „jedzie jedzie mięso" są frazami rytmicznymi, piosenkowymi, jakby zapowiadającymi niezwykłe, wyczekiwane wydarzenie. Nie przystają do opisywanej przez poetę tragicznej dla zwierząt sceny. Już w relacji podmiotu dotyczącej przewozu wspomnianych zwierząt do rzeźni, pomimo że w chwili transportu są one nadal żywymi i odczuwającymi istotami, zostają z góry określone jako "mięso". Osoba mówiąca już w samym języku, w sposobie wyrażania się na temat krów uśmierca je zatem, pokazując swój przedmiotowy stosunek do nich i obojętność na ich tragiczny los. $\mathrm{W}$ jej przekonaniu zwierzęta są mięsem nie tylko po śmierci, ale także pozostają nim za życia. Droga do rzeźni i z rzeźni niczego w istnieniu zwierzęcia nie zmienia: „Jedzie, jedzie mięso na wschód”, „wraca mięso ze wschodu”. Śliwiak w przytoczonej części poematu posuwa się jednak jeszcze dalej. Z losem „prowadzonych na rzeź” krów zbiega się bowiem los żołnierzy. Ci tak samo jak zwierzęta są masowo transportowani i już za życia zostali utożsamieni przez podmiot utworu z mięsem. Skierowani do bezpośrednich działań wojennych „na wschód”, skazani na pewną śmierć, są „mięsem armatnim". Rzeźnią jest dla nich front, na którym najczęściej giną tak, jak krowy od strzału. Jeśli żołnierze z niego wracają, to tylko martwi. Ich przeznaczenie nie różni się zatem niczym od życia zwierząt hodowlanych: „[...] dokonuje się [tu - K.N.] - jak konstatował Sobolczyk - zrównanie «mięsa» z ludźmi i ludzi ze zwierzętami w obrazie wojny jako sieci transportów kolejowych «mięsa» - do rzeźni, na front [...], do obozów, do mogił" (Sobolczyk 2009: 38).

Krowy, po przetransportowaniu do rzeźni, poddaje się uprzedmiatawiającym je czynnościom. Do akcji wkracza wówczas wagowy (najważniejsza osoba po rzeźniku), któremu Śliwiak w Poemacie... poświęca pieśń. Gatunkowo może być ona jednak co najwyżej rytmiczną piosenką, wybijającą rytm pracy wagowego: „Liczy krowy / waży krowy / kolczykuje krowie uszy” (O wagowym pieśn, P 8), „siedemset piętnaście / siedemset szesnaście...” (Areny, P 7). Czynność numerowania przywożonych do rzeźni zwierząt przywodzi na myśl po pierwsze 
tatuowanie transportowanych do obozów koncentracyjnych więźniów, po drugie tzw. nieśmiertelniki - używane w wojsku elementy z blachy z wygrawerowanym numerem identyfikacyjnym żołnierza, który miał wskazywać na jego tożsamość w razie jego śmierci bądź ranienia. W części Poematu... zatytułowanej znamiennie $N r 36625$ mieszkający na terenie ubojni i obserwujący pracujących w niej Żydów Śliwiak relacjonował:

\section{[...]}

potem wzięli ich w jednej kolumnie

do roboty do rzeźni do gnoju

$$
\begin{aligned}
& \text { płuczą Żydzi } \\
& \text { z gówien flaki } \\
& \text { jest co jeść } \\
& \text { i ciepło tu } \\
& \text { więc śpiewają } \\
& \text { Żydzi w rzeźni } \\
& \text { o jeszcze jednym } \\
& \text { przeżytym dniu }
\end{aligned}
$$

aż zwariował Żyd z tego szczęścia

i z krowami gadał

i oglądał kolczyki w ich uszach

i zapomniał kim jest już i gdzie

„ty jesteś krowa

a ja Żyd

ty jesteś mięso

a ja dym

ja numer mam

ty numer masz

ty w uchu

ja na ręce

zamieńmy się

ty swój mi dasz

za mój

co wart jest więcej”

(Nr 36625, P 13-14) 
Krowa dla Żyda staje się szczególnym obiektem zainteresowania i obserwacji. Mimo że wykonuje on przy niej „brudną robotę” - pracuje w oborze i przy uboju, patroszy ją, oczyszcza wnętrzności z kału - nie czuje wstrętu ani do mięsa, ani do zwierzęcia. Obcowanie ze śmiercią/trupem krowy nie budzi w nim żadnej psychicznej bariery przed niechcianą innością, instrumentalizacją, które mógłby zobaczyć w zwierzęciu przy obróbce mięsa. Żyd nie może się bowiem bronić przed czymś, co dotyczy także jego. Zauważa za to, że pomiędzy nim a krową nie ma granicy ani estetycznej ani egzystencjalnej, która miałaby ich rozdzielać. Łączy ich prawie wszystko. „Bycie-w-rzeźni”, „[...] jeszcze jeden / przeżyty dzień”, ów numer ewidencyjny, cierpienie, przeczucie śmierci i szczególnie okrutne unicestwienie. Szczęście pracującego w rzeźni Żyda wiąże się z przewartościowaniem przez niego pojęć i zmianą priorytetów. Kiedy myśli o przetrwaniu, najważniejsze stają się dla niego własne ciało i potrzeby fizjologiczne. Żyd, zrównując siebie jako człowieka ze zwierzęciem, czyni je równoprawnym towarzyszem spotkania i rozmowy. Z jednej strony, zachowuje się on w ten sposób z powodu pomieszania zmysłów: „zapomniał kim jest już i gdzie"; z drugiej - więzień dokonuje pewnej kalkulacji. We fragmencie wiersza, przypominającym trochę dziecięcą wyliczankę albo licytację, w której poeta oddaje głos Żydowi, najpierw zostaje wskazane to, co los przyniósł i zwierzęciu i człowiekowi: „ja numer mam / ty numer masz / ty w uchu / ja na ręce”; następnie zostaje pokazane to, co ich wartościuje, co w każdym z nich można uznać za inne/lepsze: „ty jesteś mięso / a ja dym”, „ty swój mi [numer - K.N.] dasz / za mój / co wart jest więcej”. Pierwsze z porównań wypada na korzyść krowy, po której zostanie coś materialnego po śmierci, drugie - na korzyść Żyda, który mówiąc o sobie, że „wart jest więcej”, próbuje mimo wszystko wierzyć jeszcze w swoje człowieczeństwo albo też podstępnie dokonać targu z krową, uważając, że jej los i śmierć są lepsze od jego życia i umierania w obozie, getcie, rzeźni. Żyd i krowa z tego ostatecznego rozrachunku, którego dokonali między sobą, wychodzą jednak po równo ${ }^{6}$.

6 Sobolczyk o części Poematu... zatytułowanej Nr 36625 pisał następująco: „Zwróćmy uwagę na «stopniowalność szczęścia» rozumianą jako «stopniowalność zniewoleń», czyli droga obóz - getto - rzeźnia. Także na wprowadzenie onirycznego progu, «zwariowania» $\mathrm{i}$ «snu», nim dokona się ostateczne spotkanie Ja-Ty, o którym entuzjaści filozofii Lévinasa powinni powiedzieć «Lévinasowskie», jakkolwiek filozof ten nie był «na Ty» ze zwierzętami; wegetarianizm praktykował natomiast i zalecał Martin Buber, również filozof Ja-Ty. Czy jednak uznać owo wejście w oniryczną konwencję za ustępstwo poety? «Powiem teraz coś tak dla was szokującego, że potrzebujecie znieczulającego nawiasu»? Czy też może oniryzm jest rodzajem ostatecznej nadziei Żyda, który mimo wszystko chce wierzyć, że «wart jest więcej»? (człowiek). A może propozycja wybiegu - jak równy $\mathrm{z}$ równą - ty pójdź do mojego więzienia, gdzie nic ci nie zrobią, ja zostanę w twoim i tu mnie ocalą?" (Sobolczyk 2009: 39-40). 
Krowy po kolczykowaniu przez wagowego są trzymane w zamknięciu w rzeźni aż do uboju. Śliwiak w ósmej części Poematu... napisał:

\author{
Ponumerowane \\ zamknięte w przegrodzie \\ krowy ryczące \\ w noc przed śmiercią \\ idę do was \\ przemykam się pod waszymi ciepłymi brzuchami \\ w pustym wiadrze \\ niosę dla was ulgę \\ jak więzienny spowiednik \\ każdej z was powtarzam \\ mleka odpuszczenie \\ ciała ćwiartowanie \\ żywot mleczny \\ finis
}

(Mleko, P 12)

Z przedstawionym obrazem wiąże się też inne wspomnienie z dzieciństwa poety, które ujął w zamykającym tom wierszu Wrony: „W nocy słuchałem, jak ryczą krowy, a w dzień opędzałem się od dużych, czarnozielonych much” (Wrony, P 33). To nie ryk krów wzbudza jednak niepokój w podmiocie dziecięco-młodzieńczym, ale warunki, w jakich są przetrzymywane, oraz świadomość czekającej na nie następnego dnia śmierci. W tym momencie ponownie zbiega się los krów i pracujących w rzeźni Żydów. „Teraz krowy mleczne hoduje się przeważnie w zamknięciu”, „Niektóre są trzymane w pojedynczych boksach, gdzie jest tylko tyle miejsca, by mogły stać lub się położyć”, „dostają ściśle odmierzoną ilość paszy”, „Przez dziesięć miesięcy doi się ją dwa, a czasem trzy razy dziennie. Po trzech miesiącach jest ponownie zapładniana. Doić się ją będzie aż do ósmego lub szóstego tygodnia przed następnym porodem i potem znowu, zaraz po odstawieniu cielaka”, „po czym «zużytą» krowę wysyła się do rzeźni” (Singer 2018: 230-231). Singerowskie przedstawienie traktowania krów mogłoby być opisem traktowania Żydów. Tak samo, jak przeznaczone do uboju zwierzęta, żyją oni w gettach albo obozach koncentracyjnych („Uciekł Żyd z obozu / złapali / zagnali do getta / w getcie ojciec / w getcie czterech braci / więc i getto może być rajem” - Nr 36625, P 13-14); pracują ponad siły („On pracował przy patroszeniu krowich żołądków. W kipiącej wodzie płukał je tak długo, aż stały się zupełnie czyste" - Zęby, P 28); otrzymują wydzielone porcje jedzenia albo 
głodują („Na placu obrośniętym z wszystkich stron drutami / ja Samuel - Panie Boże - stoję na pokucie / ja Samuel - czyś mnie poznał - jestem bardzo głodny" - Samuel, P 28); są wykorzystywani, rozdzielani z bliskimi, świadomi rychłej śmierci, na końcu, kiedy nie są już zdolni do pracy, są rozstrzeliwani albo prowadzeni do komór gazowych („Kiedyś Żydzi nie wrócili na noc do obozu. Zamknięto wszystkich w starej hali wieprzowej, aby ich o świcie zabić" - Zęby, P 28). Śliwiak w Poemacie... próbuje wcielić się w wybawiciela zarówno krów, jak i (w drugiej części tomu) Żydów:

Oprócz jego ojca tylko ja wiedziałem, że on tam jest. To była stara szopa, do której wrzucano nieczystości z patroszonych krowich żołądków. On siedział już trzeci miesiąc na stryszku szopy. Żywił się krwią i mlekiem przynoszonym ukradkiem przez jego ojca. Jakiż tam był smród! W obozie, z którego codziennie prowadzili Żydów do pracy w rzeźni, znowu zastrzelili kilkunastu. Wśród nich był jego ojciec. Teraz mnie przypadła rola żywiciela. Jak tam śmierdziało!

(Szopa, P 28)

Osoba mówiąca ostatecznie nie ma w sobie na tyle siły, aby uchronić przed zagładą zwierzęta, a tym bardziej Żydów. W swoich poczynaniach wykazuje się jednak człowieczeństwem i odwagą. Ostatnie, mające przynieść zwierzętom ulgę dojenie jest towarzyszeniem im w czekaniu na śmierć. Ukrywanie i karmienie Żyda w „starej szopie”, wśród cuchnących resztek z rzeźni, przedłuża natomiast jego egzystencję, chociaż niekoniecznie uchroni go przed czekającą na niego śmiercią. Krowy - dowodził Singer - „mają silną potrzebę kontaktu z «opiekunami»” (Singer 2018: 231), których w rzeźni zostały pozbawione, tak jak ukrywany Żyd zostaje pozbawiony przez Niemców ojca. Osoba mówiąca próbuje zatem zastąpić najbliższych, ale też więcej: porównuje siebie do „więziennego spowiednika”. Sobolczyk, interpretując ten fragment wiersza, dodał:

Domena metaforyczna więzienia zostaje nazwana wprost, czytelnik musi się natomiast domyślić, że chodzi o konkretny rytuał, stosowany przy karze śmierci - odwiedziny spowiednika, a także „ostatni posiłek”, tutaj niesamowicie przemienione w rytuał odpuszczenia „grzechu mleka”, który zapewne jest u krów "grzechem pierworodnym” i w optyce ludzkiej daje zamiast „żywota wiecznego” - „mleczny” (Sobolczyk 2009: 38). 
Zamiast jednak „grzechów odpuszczenia”, „ciała zmartwychwstania” i „żywota wiecznego" Żydowi podmiot oferuje tylko pożywienie i milczenie, a krowom „mleka odpuszczenie” oraz zapewnienie o „żywocie mlecznym” i „ciała ćwiartowaniu”. To ostatnie szczególnie zapada w pamięć młodego Śliwiaka. W rzeźniku zabijającym zwierzę nie ma poczucia winy ani żalu. Wykonuje mechanicznie i pewnie swoją wyznaczoną pracę, wyłącza z niej myślenie. Śliwiak nazwie ubój i wszystkie czynności z nim związane „sztuką mistrzów” (Nr 36625, P 13-14) ${ }^{7}$. Postawy rzeźnika nie zmienia nawet widok poćwiartowanych ciał, nie wzruszają go także „stygnące serca zwierząt” (Trzeci wymiar witrażu, P 22), świadczące o ich współodczuwaniu świata ${ }^{8}$. W wyobraźni młodego Śliwiaka, który na nie patrzy, organy te znajdują się dopiero w stanie agonii - stopniowo tracą swoje ciepło i zwalniają rytm bicia po wytworzonej przez zwierzęta w chwili zagrożenia śmiercią adrenalinie (szczególnie dzieje się tak przy stosowaniu tzw. uboju rytualnego). Śliwiak wcześniejszą parafrazą spowiedzi powszechnej podkreśla, że zwierzęta rzeźne, tak jak „furgony porąbanych ludzi” w Ocalonym Różewicza, nie zostaną zbawione. W rzeźni, w której obowiązuje określony, zorientowany tylko na efektywność zrutynizowany rytm pracy, wszystko musi zgadzać się „co do krowy”. Po udanym uboju rusza bowiem mająca przynosić zyski produkcja. Liczą się jej wydajność i szybkość: „[...] mięso na stół / na mydło łój / a róg na guzik do mych spodni” (Ogrody, P 6). Zwierzętom zostaje zabrane wszystko, tak jak przywożonym do obozów koncentracyjnych Żydom. I jedni, i drudzy stają się przedmiotami ogromnego przemysłu.

\section{4. Żydzi w rzeźni}

W miejskiej rzeźni pracują Żydzi z pobliskiego obozu . Rzeźnia staje się wybawieniem. Praca w niej pozwala przede wszystkim zaspokoić ich najważniejsze

7 Skojarzenie rzeźnika z mistrzem przywołuje na myśl słynną frazę Paula Celana z jego Fugi śmierci: „śmierć jest mistrzem z Niemiec” — „der Tod ist ein Meister aus Deutschland" (Celan 1988: 8-12).

8 Obraz rzeźników wielokrotnie pojawia się w wierszach Poematu... i w pierwszej, i w drugiej części. Zazwyczaj zamiast współczuć zwierzętom, cieszą się oni z „dobrego uboju”, świętując go: „herod z herodem grają w karty / [...] za dobry ubój / majster każ / odbić nam beczkę piwa z pipą” (Ogrody, P 6). Śliwiak, określając rzeźnika „herodem”, $\mathrm{z}$ jednej strony pokazuje jego okrutność i despotyczność, z drugiej - nawiązuje do postaci biblijnej, króla Judei, który po narodzinach Chrystusa zlecił wykonanie tzw. „rzezi niewiniątek” (Mt 2, 16-18).

9 W Polskim słowniku judaistycznym czytamy: „niemiecki obóz pracy i obóz koncentracyjny na przedmieściach Lwowa przy ul. Janowskiej, gdzie - po zajęciu miasta przez 
potrzeby, dlatego też, pomimo wykonywania „brudnej roboty”, wartościują ją pozytywnie: „[...] Praca w rzeźni była dobra. Można było ukradkiem napić się świeżej, zwierzęcej krwi. Zdrowej i pożywnej” (Zęby, P 28), „[...] jest co jeść i ciepło tu” (Nr 36625, P 13-14). Żydzi, aby zaspokoić głód, ukradkiem podjadają surowe mięso albo je kradną i wynoszą na zewnątrz. Uciekają się przy tym do różnych podstępów, czego wymagała konieczność odwrócenia uwagi pilnujących ich strażników. Pracując przy uboju i patroszeniu zwłok, są ofiarami nazistowskiego reżimu, ale także sami stają się oprawcami zwierząt. W Balladzie o sześciu Żydach czytamy:

Niemców (30 VI 1941) - od września tego roku znajdowała się jedna z fabryk przedsiębiorstwa zbrojeniowego SS, zatrudniająca Żydów, jako przymusową siłę roboczą. Tylko przejściowo, w początkowej fazie istnienia obozu, jego więźniami byli także Polacy i Ukraińcy, podejrzani o działalność konspiracyjną. Już w październiku 1941, kiedy zatrudniano tam ok. 600 osób, fabryka stała się zamkniętym obozem, otoczonym ogrodzeniem z drutów kolczastych [...]. Od marca 1942, na terenie utworzonego w dniach 8 XI-15 XII 1941 getta lwowskiego, przeprowadzano systematycznie akcje, których ofiary, trafiające do obozu, zatrudniane były w zakładach metalurgicznych i stolarskich. W tym samym czasie obóz służył także jako miejsce selekcji Żydów z okolicznych miast i miasteczek. Większość z nich wysyłano później do ośrodka zagłady w Bełżcu. Późną wiosną 1942 j.o. we L. powiększono, zmieniając zarazem jego charakter z obozu pracy na regularny obóz koncentracyjny, z towarzyszącymi mu zjawiskami głodu i chorób [...], bicia i zabijania, czy pracy, której jedynym celem było wyniszczenie fizyczne i psychiczne więźniów. [...] Od poł. 1943 j.o. we L. stał się w istocie także ośrodkiem zagłady; większość przywożonych tu Żydów rozstrzeliwano w pobliżu miasta, w lesie lesienickim; zwłoki zakopywano w masowych grobach, wykopanych w piaszczystej glebie; określenie «piaski» stało się we Lwowie synonimem śmierci. Tylko w maju 1943 zabito ok. 6 tys. ludzi. Mimo terroru, w obozie nierzadkie były wśród więźniów zjawiska samopomocy, m.in. opieka nad chorymi oraz próby zorganizowania ruchu oporu: szmuglowano broń i przygotowywano powstanie na czas ostatecznej likwidacji obozu. Obozowa organizacja PPR na przełomie 1942/1943 wydawała przepisywany na maszynie biuletyn, redagowany przez Edmunda Horowitza. Likwidację j.o. we L. poprzedziła w dniach 1-2 VI 1943 likwidacja lwowskiego getta, zamienionego pół roku wcześniej na obóz pracy. Około 3 tys. mieszkańców getta zabito na miejscu, ok. 7 tys. przewieziono do j.o. we L. i wkrótce rozstrzelano; w mieście nie było zorganizowanego i skonsolidowanego ruchu oporu. J.o. we L. zlikwidowano w listopadzie 1943; podczas transportowania więźniów na miejsce straceń miały miejsce pojedyncze przypadki stawiania oporu. 19 XI 1943 wybuchł bunt Sonderkommando 1005, tj. pozostawionych przy życiu Żydów, których zadaniem było zbieranie i palenie zwłok; zabito kilkunastu strażników, niektórym bojowcom udało się zbiec. Dokładna liczba ofiar j.o. we L. nie jest znana, ocenia się ją na kilkadziesiąt, a według niektórych szacunków, nawet na 200 tys. osób" (Janowski obóz we Lwowie, dostęp 2020). 


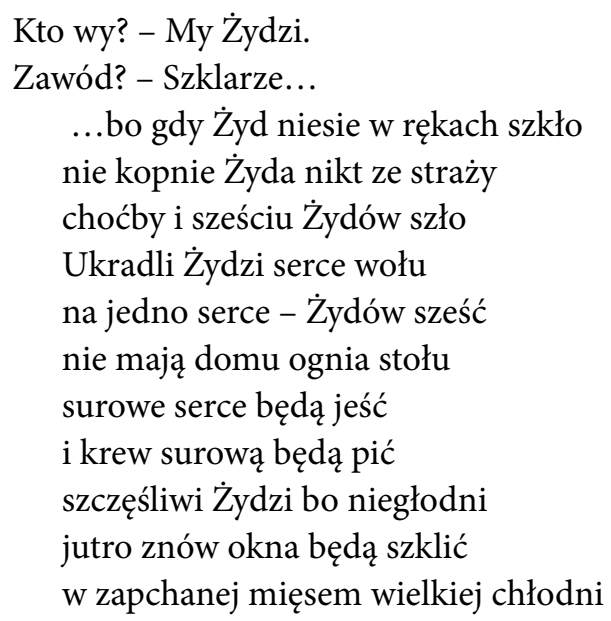

(Ballada o sześciu Żydach, P 13)

Ukazany w wierszu dialog klasyfikuje Żydów według kryteriów ekonomicznych, zawodowych, rasowych, etnicznych czy kulturowych. Szkło staje się niespodziewanie obronną tarczą więźniów przed stosowaną wobec nich przemocą. Więcej nawet: ratuje ich przed śmiercią, gdyż pod jego przykrywką Żydzi nielegalnie wynoszą mięso z rzeźni, aby zaspokoić swój głód. Śliwiak pokazuje ich dotkliwe doświadczenie braku. Kradnąc mięso, Żydzi kierują się zwykłym ludzkim instynktem. Spożywanie na surowo „serca wołu” oraz picie zwierzęcej krwi przypomina barbarzyńskie rytuały albo nawiązuje do starotestamentowego składania ofiar ze zwierząt. Żydzi pokazują w ten sposób swoją afektywną naturę, przechodzą na stronę zwierzęcości i przypominają sobie, kim tak naprawdę są i od kogo jako ludzie się wywodzą: „Jesteśmy tym, co utraciliśmy" (Ubertowska 2013: 34), co ujawnia się w skrajnych warunkach życia. Choroba głodowa, pobyt w obozie i praca w rzeźni powodują nie tylko utratę wstrętu, wrażliwości i współodczuwania z krzywdzonymi istotami, ale także rutynizację funkcjonowania: „szczęśliwi Żydzi bo niegłodni / jutro znów będą okna szklić”. Zaspokojenie głodu staje się więc warunkiem nie tylko ich przetrwania, ale - jak przewrotnie pokazuje poeta - także chwilowego szczęścia i sensu życia. Jest ono jednak trochę na wyrost. Jeśli surowego mięsa ma wystarczyć na sześciu Żydów, to tylko w śladowych, wciąż głodowych porcjach. Ale nawet dla nich więźniowie ryzykują własne istnienie, sytuując zabijanie zwierząt w ubojni oraz ich cierpienie poza dobrem i złem.

Śliwiak w swoim Poemacie... posuwa się jednak jeszcze dalej. Widział bowiem takich Żydów, którzy znajdują się w o wiele gorszym położeniu aniżeli 
pracujący w rzeźni Żydzi-szklarze. W wierszu Samuel, przynależącym do części tomu zatytułowanej Przejście przez Morze Czerwone, poeta, wykorzystując lirykę roli, napisał:

Na placu obrośniętym z wszystkich stron drutami ja Samuel - Panie Boże - stoję na pokucie ja Samuel - czyś mnie poznał - jestem bardzo głodny tym więcej jestem głodny że na moim brzuchu mam schowany kawałek kradzionego mięsa to bardzo dobre mięso ukradłem je w rzeźni ono jest ciepłe grzeję je swym głodem gdybym zechciał je wyjąć - zaraz padłby strzał esesmani na wieżach śmieją się to oni postawili mnie tutaj - a stać mam tak długo dopóki mięsa na brzuchu nie zjedzą robaki tego dobrego kradzionego mięsa

(Samuel, P 27)

Utwór ten jest jednym z najdramatyczniejszych wierszy cyklu. Wcześniej podmiot przemawiał przede wszystkim z perspektywy obserwatora wydarzeń, teraz oddaje głos więźniowi obozu koncentracyjnego, który przyłapany na kradzieży mięsa z ubojni, zostaje dotkliwie ukarany przez niemiecką straż. Co ważne, nie mamy do czynienia $\mathrm{z}$ anonimowym Żydem, ale z konkretną osobą, którą poeta nazywa po imieniu. Samuel, z języka hebrajskiego szemu’el, oznacza 'wysłuchany przez Boga' lub - według Księgi Samuela - 'uproszony u Boga' (Dziadosz 2012: 998). W nawiązaniu do pierwszego z tłumaczeń wypowiadane w wierszu słowa zamieniają się w modlitwę Żyda. W utworze szczególnie wybrzmiewa dwukrotne zawołanie podmiotu: „ja Samuel” oraz skierowane do Boga pytanie: „czyś mnie poznał”. Można odnieść wrażenie, że za tymi frazami jest ukryte coś więcej. Stojący „na placu obrośniętym z wszystkich stron drutami” Żyd być może ma swój pierwowzór w biblijnym Samuelu: „militarnym i duchowym przywódcy pokoleń Izraela w walce z Filistynami”, „prawnym administratorze zajmowanych przez Izraelitów terytoriów”, „duchowym zwierzchniku decydującym w imieniu Boga o kształcie ich społecznej struktury”, „mającym tajemną wiedzę i bezpośredni kontakt z Bogiem ("widzący»), roztaczającym duchową troskę nad podległymi mu terenami”, wreszcie „proroku, który objawia wolę i moc Jahwe” (Dziadosz 2012: 998). To wszystko okazuje się jednak 
niczym. Samuel zdaje się być tutaj reprezentantem wszystkich więźniów, którzy przed wojną znaczyli w społeczeństwie coś więcej. W utworze zatytułowanym Zęby Śliwiak przedstawia Żyda potrafiącego grać na zębach, co budzi zachwyt u jednego Niemca. Umiejętność ta w obozie Zagłady jest więcej warta, aniżeli wiedza i zdolności „[...] kilku dobrych chirurgów, inżyniera chemika i malarza”. „Kiedy wszystkich ich zastrzelili” - relacjonował autor Widnokresu - „pozostał tylko on”, ów Żyd, potrafiący zagrać na zębach „W lasku Idy trzy boginie...”. Dzięki swojej zdolności „Nie wracał już do obozu. Co wieczór przychodził do Niemców i grał. Zamieszkał w psiarni, na słomie, wśród czarnych, niemieckich wilczurów”. Chociaż ostatecznie nie został zgładzony jak inni, dla oprawców był tylko kolejnym zwierzęciem: „Niemcy też przyzwyczajają się do zwierząt. Lubią ich różne sztuczki. Kiedy którejś nocy uciekł od nich, czuli żal. Taki sam żal, jakim darzy się psa, który okazał się niewierny” (Zęby, P 28-29).

Prawego, silnego, odważnego, cenionego, charyzmatycznego i pobożnego Samuela obozowy głód przemienia w więzionego, owładniętego lękiem, niemającego na nic wpływu, wystawionego na pośmiewisko oprawców złodzieja mięsa, którego Bóg raczej nie ma szans uratować. Żyd zostaje zdegradowany i skazany na pewną śmierć. Czy umrze zastrzelony przez esesmanów, czy z głodu, jego ciało, którego częścią stało się także „kradzione mięso”, i tak będzie zjedzone przez robaki. Podział na ludzkie i zwierzęce w obliczu śmierci i w sytuacji rozkładu ciała/padliny jest zniesiony. Sam obraz wystraszonego Żyda, stojącego „na placu obrośniętym z wszystkich stron drutami”, obserwowanego przez Niemców, czekających na jego jeden fałszywy ruch, przypomina obraz zwierzęcia zamkniętego w klatce. Obóz koncentracyjny można więc z powodzeniem porównać do ogrodu zoologicznego (co także wyjaśnia tytuł wiersza otwierającego Poemat...). Patryk Szaj, analizując utwory Różewicza, wskazywał:

Nie bez znaczenia jest oczywiście fakt, że akcja obu utworów (***[urodziłem się nosorożcem...] i Nosorożca - K.N.) rozgrywa się w ogrodzie zoologicznym, nazywanym przez Czaję „łagodną postacią obozu koncentracyjnego". To z pozoru arbitralne utożsamienie przywodzi na myśl antropologiczne rozważania Johna Bergera, który nie wahał się stwierdzić, że „wszystkie miejsca wymuszonej marginalizacji - getta, dzielnice slumsów, więzienia, domy dla obłąkanych, obozy koncentracyjne - mają coś wspólnego z ogrodami zoologicznymi”. Jeśli jednak zoo miałoby być obozem koncentracyjnym, to jak należałoby nazwać rzeźnię? Czy - jak sam Różewicz w wierszu Ucieczka świnek dwóch... „obozem zagłady” [...]? (Szaj 2017: 38). 


\section{5. Życie w rzeźni}

„[... Dzieciństwo spędzone na terenie rzeźni i w okresie masowej rzezi” (Sandauer 1981: 481) było dla młodego Śliwiaka szkołą życia. Przemoc, krew, zabijanie ludzi i zwierząt, wojna, głód to codzienność, z którą musiał się mierzyć. Autorowi Chityny trudno było uwierzyć w istnienie usytuowanej gdziekolwiek innej, lepszej rzeczywistości:

[...] Kiedy dowiedziałem się, że na świecie żyją nie tylko tacy, co strzegą, zabijają i jedzą mięso - zapragnąłem ich zobaczyć. Pokazali mi strażaka w srebrnym kasku. I konduktora, który jeździł po mieście czerwonym tramwajem. Potem zobaczyłem zakonnicę i profesora z teczką pełną książek. I kataryniarza z kolorowym ptakiem. On grał, a ja słuchałem. To było ładne, tak ładne, że pomyślałem: kiedy nie będę musiał już mieszkać w rzeźni - zostanę kataryniarzem. Ale mieszkałem tam dalej.

\section{(Wrony, $\mathrm{P}$ 22)}

Poeta, obserwując zagładę zwierząt i Żydów, uczy się w ubojni „nowych słów i praw”, „rozróżniania / wszystkich barw wroga” oraz nie tylko gramatycznego podziału na „my” i „oni” (Bożek, P 11). „My” to wszyscy ocaleni - zarówno ludzie, jak i zwierzęta, „oni” to oprawcy. Do pierwszych Śliwiak zalicza chociażby pojawiającego się na targu zwierząt staruszka, który „[...] w każdy / wtorek sprzedawał tę samą parę gołębi” tylko po to, aby na drugi dzień do niego wróciły i „aby mógł je sprzedać znowu” i „zarobić na swój chleb / i ich ziarno” (Targowica zwierząt, P 11), jak również wydobytego „z łona zarżniętej owcy” „malutkiego, czarnego baranka”, który został podarowany przez rzeźnika matce poety na imieniny (Upominek, P 31). Do drugich - śmierć, która ukrywa się pod zbroczonymi krwią, sztywnymi fartuchami rzeźników oraz pod pilnującymi wejścia do rzeźni mundurami strażników i nazistów. Śliwiak, próbując zrozumieć „pierwsze prawo wilka” i „ostatnie prawo człowieka”, uświadamia sobie, że granice pomiędzy „ludzkim” i „zwierzęcym” nie istnieją, że należy pogodzić się z obecną w człowieku animalistyczną częścią istnienia, która nie uprawnia go do uważania siebie bezwzględnie za istotę nadrzędną. W obliczu wojny, śmierci, Zagłady wszyscy cierpią tak samo, zamiennie wchodzą w role katów i ofiar, a w ostatecznym rozrachunku stają się wobec siebie równi. Siedem lat spędzonych w rzeźni, zapamiętane dramatyczne obrazy „stada / ryczących krów / pędzonych jak rzeka / do czerwonego morza rzeźni” (Nad Morzem Czerwonym, $\mathrm{P}$ 26), przeżyta $\mathrm{z}$ dziecięcego punktu widzenia okupacja są dla 
poety zdarzeniami traumatycznymi, z którymi w chwili pisania Poematu... jest już pogodzony. Dziecięce, psychiczne rany autora Chityny, które otwarły się w rzeźni, zrosły się po latach: „Zdarzenia te pozostawiły w mojej świadomości trwałe blizny pamięci” (Śliwiak 1975: 10, wyróż. - K.N.). Bywa jednak, że wszystkie uznane za zabliźnione, trudne doświadczenia powracają do niego mimowolnie: „Dziś już nie mieszkam w rzeźni. Ale wystarczy, aby zgasło światło dnia, a zaraz nad moim domem pojawiają się wrony. Jest ich dużo. Odlatują dopiero o świcie” (Wrony, P 22).

\section{| Bibliografia}

Celan Paul (1988), Wiersze, wybór, przeł., posł. Feliks Przybylak, Kraków.

Cioran Emilè (2004), Zeszyty 1957-1972, słowo wstępne Simone Boué, przeł. i opatrzył przypisami Ireneusz Kania, Wydawnictwo KR, Warszawa.

Coetzee John Maxwell (2006a), Życie zwierząt. Poeci i zwierzęta, przeł. Zbigniew Batko, w: tenże, Elizabeth Costello, Znak, Kraków, s. 109-136.

Coetzee John Maxwell (2006b), Życie zwierząt. Filozofowie i zwierzęta, przeł. Zbigniew Batko, w: tenże, Elizabeth Costello, Znak, Kraków, s. 72-108.

Czechowicz Józef (1970), Wybór poezji, oprac. Tadeusz Kłak, Zakład Narodowy im. Ossolinskich, Wrocław-Warszawa-Kraków.

Dziadosz Dariusz (2012), Samuel [hasło], w: Encyklopedia katolicka, t. 17: Republika - Serbia, Towarzystwo Naukowe Katolickiego Uniwersytetu Lubelskiego Jana Pawła II, Lublin, s. 998-999.

Janowski obóz we Lwowie, w: Polski słownik judaistyczny, https://tinyurl.com/5xcudysk [dostęp: 7.05.2020].

Jarzyna Anita (2019), Post-koine. Studia o nieantropocentrycznych językach (poetyckich), Wydawnictwo Uniwersytetu Łodzkiego, Łódź.

Krupiński Piotr (2016), Dlaczego gęsi krzyczały? Zwierzęta i Zagłada w literaturze polskiej XX i XXI wieku, Instytut Badań Literackich PAN, Warszawa.

Kryska Sławomir (1966), Poemat o miejskiej rzeźni, „Kultura”, nr 27, s. 8.

Loba Mirosław (2017), Zagłada, ofiara i zwierząt w myśli Elisabeth de Fontenay, „Narracje o Zagładzie”, nr 3, s. 42-50.

Patterson Charles (2003), Wieczna Treblinka, przeł. Roman Rupowski, Vega!POL, Opole.

Pieńkosz Konstanty (1986), Świat nadziei paradoksalnej, w: Śliwiak Tadeusz, Koń maści muzycznej, wstęp i wybór Konstanty Pieńkosz, Wydawnictwo Literackie, Kraków, s. 5-13. 
Sandauer Artur (1981), Poezja tragicznego ładu (Rzecz o Tadeuszu Śliwiaku), w: tenże, Zebrane pisma krytyczne. Studia o literaturze współczesnej, Państwowy Instytut Wydawniczy, Warszawa, s. 467-483.

Singer Peter (2018), Droga przez ferme przemysłowa. Czyli co się przydarzyło twojemu obiadowi, kiedy był jeszcze zwierzęciem, w: tenże, Wyzwolenie zwierząt, przedmowa Yuval Noah Harari, przeł. Anna Alichniewicz, Anna Szczęsna, Marginesy, Warszawa, s. 174-256.

Sobolczyk Piotr (2009), „Ty jesteś krowa a ja Żyd”. Tadeusza Śliwiaka Holocaust zwierząt, „Pogranicza”, nr 5, s. 28-40.

Szaj Patryk (2017), Niepokoje. Tadeusz Różewicz wobec tzw. zwierząt hodowlanych, „Narracje o Zagładzie”, nr 3, s. 121-138.

Śliwiak Tadeusz (1965), Poemat o miejskiej rzeźni, Wydawnictwo Literackie, Kraków.

Śliwiak Tadeusz (1975), Wstęp, w: Poezje wybrane, wyboru dokonał i wstępem opatrzył Tadeusz Śliwiak, Ludowa Spółdzielnia Wydawnicza, Warszawa, S. 5-11.

Śliwiak Tadeusz (1988), Od autora, w: tenże, Poezje wybrane, wstęp i wybór Tadeusz Śliwiak, posłowie Jan Pieszczachowicz, Ludowa Spółdzielnia Wydawnicza, Warszawa, s. 5-8.

Ubertowska Anna (2013), Natura u kresu (ekocyd). Podmiotowość po katastrofie, „Teksty Drugie”, nr 1-2, s. 33-44.

\section{| Abstrakt}

\section{KatARZyNA NiEsPoreK}

\section{Zagłada zwierząt i ludzi. Lektura Poematu o miejskiej rzeźni Tadeusza Śliwiaka}

Przedmiotem artykułu jest interpretacja Poematu o miejskiej rzeźni zapomnianego poety Tadeusza Śliwiaka. Poeta swoim utworem i postawieniem znaku równości pomiędzy rzeźnią a obozem koncentracyjnym, cierpieniem Żydów i zwierząt hodowlanych, wkroczył w temat, który współcześnie jest chętnie podejmowany. Próbując zrozumieć „pierwsze prawo wilka” i „ostatnie prawo człowieka”, uświadamia sobie, że granice pomiędzy „ludzkim” i „zwierzęcym” nie istnieją, że należy pogodzić się z obecną w człowieku animalistyczną częścią istnienia, nieuprawniającą go do uważania siebie za istotę nadrzędną. W obliczu wojny, śmierci, Zagłady wszyscy cierpią tak samo, zamiennie wchodzą w role katów i ofiar, a w ostatecznym rozrachunku stają się wobec siebie równi. 
Słowa kluczowe: Tadeusz Śliwiak, Poemat o miejskiej rzeźni, zwierzęta, Żydzi, Zagłada

\section{| Abstract \\ Katarzyna Niesporek \\ The Extermination of Animals and Men: On Tadeusz Śliwiak's Poemat o miejskiej rzeźni}

The aim of the article is an interpretation of Tadeusz Sliwiak's Poemat o miejskiej rzeźni. Śliwiak puts equal signs between the slaughterhouse and the concentration camp, and between the suffering of Jews and farm animals with which he enters the modern discussion on these matters. The poet, trying to understand "the first law of wolf" and "the last law of man", realizes that there are no boundaries between "human" and "animal"; that one should accept the animalistic part of human existence. In the perspective of war, death and extermination, everyone suffers likewise.

Keywords: Tadeusz Śliwiak, Poemat o miejskiej rzeźni, farm animals, extermination, Jewry

\section{| Biogram}

Katarzyna Niesporek - dr, adiunkt w Instytucie Literaturoznawstwa Uniwersytetu Śląskiego w Katowicach. W kręgu jej zainteresowań badawczych znajduje się krajowa i emigracyjna poezja polska drugiej połowy XX wieku, literatura na Górnym Śląsku oraz twórczość najnowsza. Artykuły naukowe i recenzje ogłaszała w tomach zbiorowych i czasopismach. Autorka monografii „Ja” Świetlickiego (2014); Eda. Szkice o wyobraźni i poezji (2015); Boskie, ludzkie. Studia o poetyckim doświadczaniu Boga (2017), Hałda. O śląskiej wyobraźni symbolicznej (2019). Współredaktorka tomów zbiorowych.

E-mail: katarzyna.niesporek@us.edu.pl

ORCID: 0000-0001-7103-9285 